\title{
Price Balance for the Good of Consumers and Business Actors
}

\author{
Darmadi Durianto ${ }^{1}$, Slamet Riyadi ${ }^{2}$, Faisal Santiago ${ }^{3}$ \\ Universitas Borobudur, Jakarta Utara-DKI Jakarta ${ }^{1}$, Universitas Borobudur, Bogor-Jawa \\ Barat $^{2}$, Universitas Borobudur, Jakarta Timur-DKI Jakarta ${ }^{3}$ \\ \{Darmadidurianto25@gmail.com¹, Didislametriyadim.si@gmail.com², \\ faisalsantiago@borobudur.ac.id $\left.{ }^{3}\right\}$
}

\begin{abstract}
Building a house relies on the availability of raw materials, among which is cement. Consumers in Indonesia usually consider the price in choosing cement. A slight difference in price of one sack means a lot of multipliers. The recent trial at the Business Competition Supervisory Commission sentenced PT Conch South Kalimantan Cement $(\mathrm{CONCH})$ to guilty of allegedly selling cement at under-market prices. Evidences include a financial report on CONCH's lost money and the removal of other brands from the market in a region. The KPPU commission panel judged $\mathrm{CONCH}$ to be selling losses to get rid of competitors. On the other hand, the cheap selling by $\mathrm{CONCH}$ had benefitted consumers. However, after $\mathrm{CONCH}$ was deemed guilty and fined, $\mathrm{CONCH}$ would sell cement at above its usual price or according to market standards. This of course affects consumers. The purpose of this research is to find out the root causes of the KPPU's decision on $\mathrm{CONCH}$ and the impact of this decision on consumers. Our research aims to provide suggestions so that the KPPU's decision will not affect consumers. Thus, it is necessary to regulate a system without predatory pricing or selling price determination by producers that is burdensome to consumers.
\end{abstract}

Keywords: Cement Price; Business Competition Supervisory Commission; National Consumer Protection Agency; Business Competition Law; Consumer Protection Law

\section{Introduction}

Indonesia is a country that adheres to an economic democracy that prioritizes the interests of the people [1]. For the welfare of the Indonesian people, the development of various types of industrial fields needs to be encouraged. In addition, to manifest the implementation of the Indonesian economy which is in line with the mandate of Article 33 paragraph (4) of the 1945 Constitution of the Republic of Indonesia, the national economy must be managed based on economic democracy with the principles of togetherness, efficiency with justice, sustainability for the future, environmentally-sound, independence, and maintaining the balance of progress and the unity of the national economy of the State. 
The development of life today which is increasingly modern has led to changes in the lifestyle of a group of people, including those in Indonesia. Modern living creates the need for housing from landed houses to apartments. This has prompted a large number of cement industries in Indonesia to take advantage from this demand of housing, providing public or consumers with an array of options.

In this study, we provide problem formulations in two problem identifications. The first problem is to find out the root causes of the KPPU's decision on $\mathrm{CONCH}$. The second problem is to find out ways to prevent the KPPU's decision from having a bad impact on consumers, especially those from lower class. We raise this second problem because when KPPU punishes a business actor because it is considered to have committed an act of cheap selling, the business actor will automatically increase/mark-up the selling price of the cement. Therefore, a system needs to be created to avoid predatory pricing and selling price that is too burdensome for consumers.

\section{Methodology}

The research method used in this research is the empirical juridical method by analyzing primary data and some secondary data. Primary data are regulations related to buying and selling, while secondary data are legal literature, related journals, and dictionaries related to the problems in this study. Thus, this research not only refers to materials in the form of legal theory, concepts, principles, and regulations related to the research topic, but also explains the reality in society as a legal phenomenon for the subject, namely society as a consumer. All the data needed by researchers in assessing the research problems were collected using literature review technique.

Researchers then analyzed the data qualitatively by conducting an in-depth analysis. Specifically, researchers conducted in-depth interviews and Focus Group Discussions to provide the required empirical data. The interviewees/participants were selected purposively from various backgrounds which were then categorized as government and related institutions as well as practitioners and academicians.

\section{Results and Discussion}

In accordance with the 1945 Constitution of the Republic of Indonesia, the Indonesian State has the aim to protect all the people of Indonesia and their entire native land. In addition, the 1945 Constitution as the basis for regulations needs to provide legal protection to ensure the rights of every member of Indonesian society.

The life of Indonesian society today demands permanent residence, either a landed house or an apartment. This has encouraged many cement industries in Indonesia to take advantage of this open market. According to the data obtained, cement sales in the South Kalimantan region are not small. One of the CONCH company's reports to the KPPU stated that their cement production in 2019 was 3.1 million tons [2]. 
Table 1. Comparison of Production Volume and Production Capacity

SALINAN

Terlapor

\begin{tabular}{|c|c|c|c|}
\hline Tahun & $\begin{array}{c}\text { Volume Produksi } \\
\text { (ton) }\end{array}$ & $\begin{array}{c}\text { Kapasitas } \\
\text { Produksi }\end{array}$ & Persentase \\
\hline 2014 & 23.238 & 1.550 .000 & $1,49 \%$ \\
\hline 2015 & 863.370 & 1.550 .000 & $55,70 \%$ \\
\hline 2016 & 1.533 .292 & 2.450 .000 & $62,58 \%$ \\
\hline 2017 & 1.683 .657 & 3.100 .000 & $54,31 \%$ \\
\hline 2018 & 1.940 .645 & 3.100 .000 & $62,60 \%$ \\
\hline 2019 & 1.877 .716 & 3.100 .000 & $60,57 \%$ \\
\hline
\end{tabular}

From the table above, it can be seen that the amount of cement production has increased from year to year. In 2014, the amount of production reached 23 thousand tons, but, in 2019, the amount of production increased rapidly, reaching 1.8 million tons. This is what prompted $\mathrm{KPPU}$, as a law enforcement agency, to suspect an unfair competition at CONCH because the increase in cement production was deemed unusual in several years.

Carrying out a law enforcement function in line with development is not something easy because it is a complex human problem that is considered a social reality [3]. The State needs to provide protection to every citizen in the framework of law enforcement which is based on justice. In the economic sector, for example, Indonesia requires the State to provide protection to consumers in buying and selling transactions. The selling price of a good or service should not be too expensive for all levels of society, both the middle and lower classes. This balance should be regulated by the two existing state institutions, namely KPPU and BPKN.

The Business Competition Supervisory Commission (Komisi Pengawas Persaingan Usaha/KPPU) is the agency in charge of overseeing the implementation of Law Number 5 Year 1999 concerning the Prohibition of Monopolistic Practices and Unfair Business Competition. This rule authorizes KPPU to carry out investigations of business actors, witnesses, and other parties, either because of reports or based on the KPPU's own initiative. In conducting investigations, both on the basis of KPPU's initiative and on the basis of reports, KPPU follows a number of procedures, starting with how a case becomes a business competition case and is investigated by KPPU until the KPPU reaches a verdict. After KPPU issues a verdict, the law also provides an alternative for business actors subject to that verdict [4].

The National Consumer Protection Agency (Badan Perlindungan Konsumen Nasional/BPKN) is the embodiment of legal protection for consumers provided by the State to its people. In carrying out its duties, BPKN acts as an advisor to the State in an effort to actualize consumer protection as stated in Law Number 8 of 1999 concerning Consumer Protection. The Agency is appointed by a President's decision and directly responsible for the results of its performance to the President [5].

\section{a) Legal Protection for Consumers, Especially in Sales of Building Material Needs}

Efforts to develop consumer protection cannot be separated from international and national dynamics, all of which affect the dimensions of law, policy, institution, logistical transactions, and also the management of protection for consumers. In order to achieve the noble ideals of 
the Indonesian people, Article 33 paragraph (4) of the 1945 Republic of Indonesia Law has interpreted that "the national economy is organized based on economic democracy with the principles of togetherness, equitable efficiency, sustainability, and insight about the environment, with independence and the maintainence of a balance between progress and national economic unity." The practice of buying and selling between business actors and consumers needs to provide justice between the two.

The current development of investment has opened up opportunities for foreign business actors to run their business in Indonesia. Business actors simultaneously open factories and employ their workers who are imported directly from their countries. One of the successful businesses in Indonesia is $\mathrm{CONCH}$. This cement company has succeeded in increasing its production many times in a matter of years (see the table below) [6].

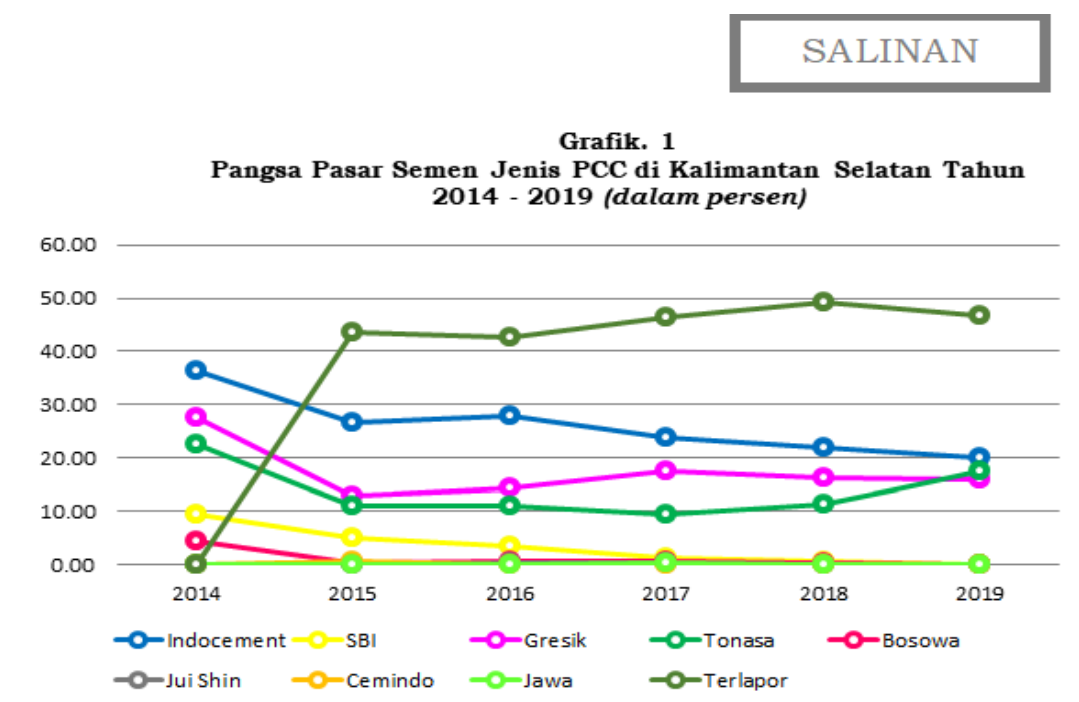

From the data above, it is explained that CONCH's cement market share continued to increase from 2014 to 2019. It is different from the KPPU's point of view which considers that there have been intentional actions to remove other cement players from the market. With regards to BPKN, the increase and stability of the CONCH's cement business in the South Kalimantan region shows that consumers prefer this cement to other cements. The cement business in Indonesia is one of the businesses that is of concern to the government. Even in Presidential Decree No. 71 of 2015, the central government determines the types of Basic Needs and/or Important Goods as referred to in Paragraph (1), as follows: 1) seeds, namely rice, corn and soybean seeds; 2) fertilizer; 3) LPG gas of 3 (three) kilograms; 4) plywood; 5) cement; 6) iron steel for construction; and, 7) mild steel.

Under certain conditions that can disrupt national trade activities, the central government is obliged to ensure the supply and stabilization of prices for basic necessities and essential goods. Because of this, the emergence of $\mathrm{CONCH}$ from the consumers' point of view is a breath of fresh air if they want to build housing or other things. The low price offered of course has a good impact on consumers. 


\section{b) The Basis for the KPPU's Decision on CONCH}

With the issuance of the KPPU's decision on January 15, 2021 with case number 03/KPPU-L/2020, CONCH was proven to have violated Article 20 of Law Number 5 of 1999 in the sale of Portland Composite Cement (PCC) type cement in the South Kalimantan region. Therefore, $\mathrm{CONCH}$ was fined in the amount of IDR 22,352,000,000 (twenty-two billion three hundred and fifty-two million rupiah) because the company was considered to have carried out predatory pricing or selling cement at a loss in the South Kalimantan region. The decision of the KPPU panel was based on several considerations, such as the opinion of an expert based on the testimony of DR Jur Udin Silalahi, SH, LL.M, who, in essence, stated that business actors can sell at a loss or set very low prices with capital or financial support from large business actors.

The practice of selling at a loss with the aim of eliminating or killing business competitors in the market in the context of business competition is a behavior of business actors who generally have a dominant position in the market or as an incumbent business actor fixing prices that are economically detrimental for a long time. This strategy may result in competitors being eliminated from the relevant market and/or prevent other business actors from entering the market.

The third consideration is based on a report from the Cement Association that the company's market domination was up to 43.65 percent, whereas in the previous year it was still 0 percent. In addition, there was a financial report from PT CONCH which states that there have been losses in several years. This, of course, is the basis for a decision on the practice of predatory pricing or selling at a loss.

Table 2. Pangsa Pasar Semen Jenis PCC di Wilayah Kalimantan Selatan Tahun 2014-2019

(dalam persen)

\begin{tabular}{|l|c|c|c|c|c|c|}
\hline \multirow{2}{*}{ Pelaku Usaha } & \multicolumn{7}{c|}{ Tahun } \\
\cline { 2 - 8 } & 2014 & 2015 & 2016 & 2017 & 2018 & 2019 \\
\hline PT Indocement Tunggal Prakarsa Tbk & 36,25 & 26,65 & 28,02 & 23,84 & 22,08 & 19,99 \\
\hline PT Solusi Bangun Indonesia & 9,38 & 4,84 & 3,27 & 1,30 & 0,69 & 0,06 \\
\hline PT Semen Gresik Tbk & 27,52 & 12,98 & 14,37 & 17,61 & 16,39 & 15,99 \\
\hline PT Semen Tonasa Tbk & 22,43 & 10,92 & 10,97 & 9,37 & 11,29 & 17,40 \\
\hline PT Semen Bosowa Maros & 4,42 & 0,28 & 0,57 & 0,70 & 0,23 & - \\
\hline PT Jui Shin Indonesia & - & 0,03 & 0,28 & 0,42 & - & - \\
\hline PT Cemindo Gemilang & - & 0,66 & - & - & - & - \\
\hline PT Semen Jawa & - & - & 0,01 & 0,28 & - & - \\
\hline Terlapor & - & 43,65 & 42,51 & 46,48 & 49,32 & 46,56 \\
\hline \multicolumn{1}{|c|}{ TOTAL } & 100 & 100 & 100 & 100 & 100 & 100 \\
\hline
\end{tabular}

The KPPU's decision is in accordance with Law No. 5/1999 concerning the prohibition against selling at a loss. However, apart from having a positive side, this decision also had a negative side. On the negative side, this decision is detrimental to consumers because after this decision was made, PT CONCH will raise the selling price of its cement or make it at least equal to the market price. This will make it difficult for consumers who need building materials, such as cement, at low prices. 
The implementation of regulations in force in a country, in addition to creating justice, also needs to pay attention to the deterrent aspect for those who violate it. The existing legal rules need to make a balance in people's lives today, as quoted in the book written by Lili Rasjidi et al. regarding the Theory of Development Law which describes that law is a tool to maintain order for people in a society. It is important to note that the function of the nature of law is basically that the law must be to maintain what has been achieved [7]. It is also in line with the Legal Development Theory put forward by Prof. Dr. Mochtar Kusumaatmaja, SH., L.LM., who states that the Legal Development Theory globally contains aspects, such as: According to him, the Legal Development Theory is a legal theory known to many people in Indonesia because it was created by Indonesians from observing the dimensions and culture of Indonesian society; Then in broad terms, the Legal Development Theory uses a frame of reference based on the way of life of the Indonesian people according to the principles of Pancasila; And basically, the Legal Development Theory provides the basis for the function of law as a "means of community reform" (law as a tool for social engineering) and law as a system which is indispensable for the people of Indonesia as a country that is included in the category of developing countries [8].

\section{Recommendations}

Based on the elaboration of the problems in this study, we have several recommendations for the creation of legal reforms that are in accordance with the conditions of society so that consumers' rights can be quickly restored and also so that business actors carry out their obligations in full, as follows:

a. Cooperation between BPKN and KPPU should be increased, given the development of business competition, which, on the other hand, can make price increases harm consumers.

b. Legal reforms at BPKN shall be encouraged, and this can be done through the new National Consumer Protection Agency Draft Law because the current regulations are no longer in accordance with the development of modern society, especially in the foreign investment business sector.

c. The Ministry of Trade ought to be more active in monitoring the circulation of cement prices because the Ministry of Trade has the Directorate General of Consumer Protection and Trade Order. In practice, the Ministry of Trade can open a direct service for complaints from the public regarding the price of cement.

d. The determination of predatory pricing must look deeper at the level of efficiency of each player; it could be due to the inefficiency of PT Semen Indonesia that its cement price is more expensive than that of PT $\mathrm{CONCH}$, which carries out efficiency.

e. There must be a balance of cement prices as determined by lower and upper tariffs so that consumers are protected from the quality of goods because they are cheap but are also protected from high prices from business actors seeking excessive profit.

\section{References}

[1] TAP-MPR-XVI-MPR-1998 Article 1

[2] http://putusan.kppu.go.id/simper/menu/ 
[3] Faisal Santiago, MA Sebagai Benteng Terakhir (Peradilan) Penegakan Hukum, artikel dalam buku Akuntabilitas Mahkamah Agung Asosiasi Pimpinan Perguruan Tinggi Hukum Indonesia, PT. Rajagrafindo Persada, Depok, 2016 page 24.

[4] Andi Fahmi Lubis, et al, Hukum persaingan usaha Antara Teks dan Konteks, Jakarta : Deusche Gesellschaft furtechnische zusammenarbeit (GTZ) page 147

[5] Accessed from http://economy.okezone.com/amp/2019/02/07/320/2014790/presidenjokowi-beri-tugas-baru-badan-perlindungan-konsumen-nasional?page $=1$

[6] Ibid. Putusan KPPU

[7] Lili Rasjidi dan Ida Bagus Wiyasa Putra, Hukum Sebagai Suatu Sistem,CV. Mandar Maju, Bandung, 2003, page 5.

[8] Lilik Mulyadi, Teori Hukum Pembangunan Prof. DR. Mochtar Kusumaatmadja, SH., L. LM, Kajian Deskriftif Analitis, accessed on 23 September 2020 at 12.17. 